\title{
Üniversite Öğrencilerinin Çevre Bilinçlerinin İncelenmesi: Ondokuz Mayıs Üniversitesi Örneği
}

\author{
Seyfullah GÜL \\ Ondokuz Mayıs Üniversitesi, Turizm Fakültesi \\ seyfullah.gul@omu.edu.tr \\ Mücahit AYDOĞMUŞ \\ Ondokuz Mayıs Üniversitesi, Eğitim Fakültesi \\ mucahitaydogmus19@gmail.com \\ İ. Hakan ÇOBANOĞLU \\ Samsun Üniversitesi, Kavak Meslek Yüksekokulu \\ ihcobanoglu@hotmail.com \\ Harun TÜRK \\ Samsun, Milli Eğitim Müdürlüğü \\ harunturk5@gmail.com
}

Gönderilme Tarihi: 25/06/2018

Kabul Tarihi: 26/11/2018

Yayınlanma Tarihi: 30/11/2018

DOI: $10.30855 /$ gjes.2018.04.03.002

\begin{tabular}{|c|c|}
\hline Makale Bilgileri & ÖZET \\
\hline $\begin{array}{l}\text { Anahtar } \\
\text { Kelimeler: } \\
\text { Çevre, } \\
\text { Çevre bilinci, } \\
\text { Çevre sorunları, } \\
\text { Üniversite } \\
\text { öğrencileri }\end{array}$ & 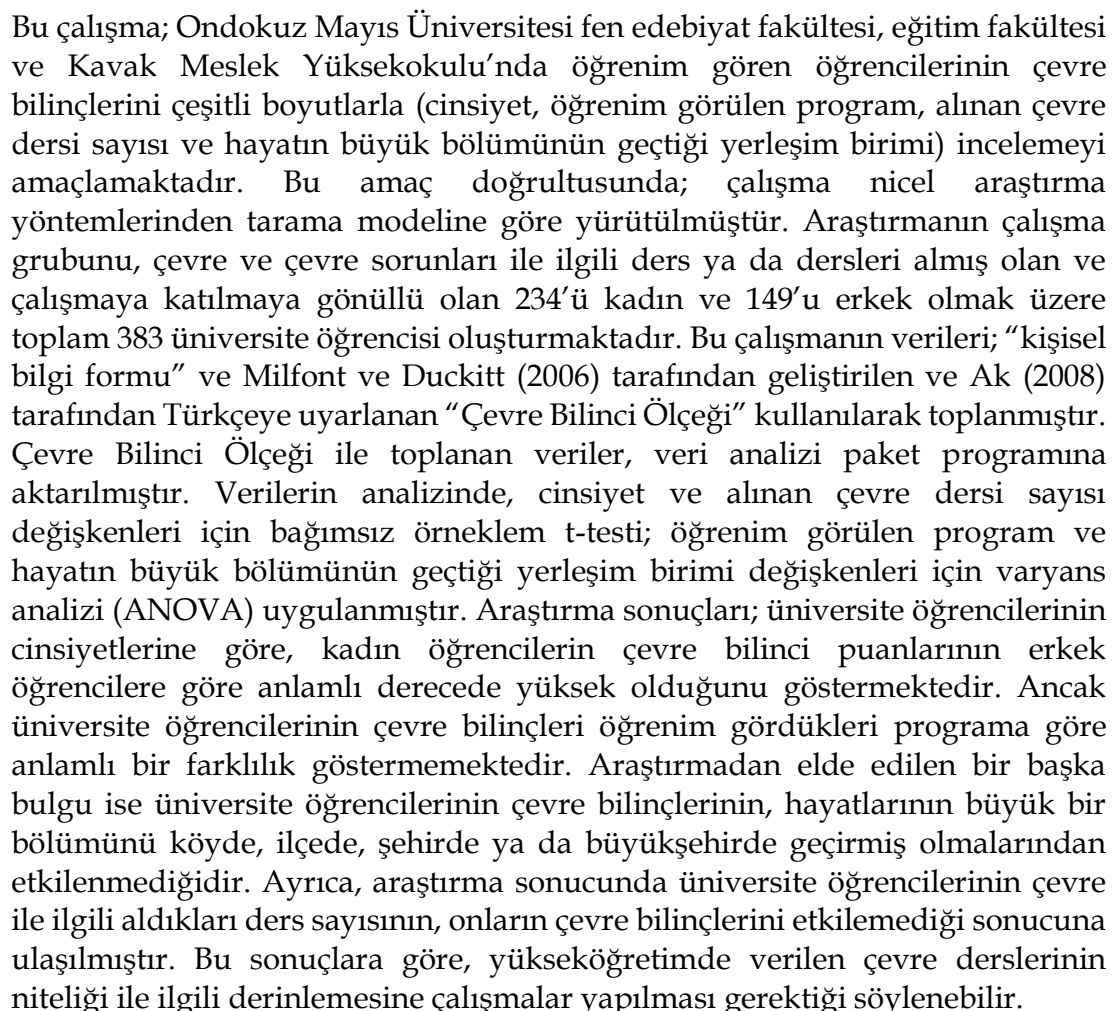 \\
\hline
\end{tabular}

Gül, S., Aydoğmuş, M., Çobanoğlu, İ. H., \& Türk, H. (2018). Üniversite öğrencilerinin çevre bilinçlerinin incelenmesi: Ondokuz Mayıs Üniversitesi örneği. Gazi Ĕ̆itim Bilimleri Dergisi, 4(3), 13-28. DOI: https://dx.doi.org/10.30855/gjes.2018.04.03.002.

Dergi Web Sayfast: http://dergipark.gov.tr/gebd 


\section{Investigation of Environmental Consciousness of University Students: The Sample of Ondokuz Mayıs University}

\begin{tabular}{l} 
Article Info \\
\hline Keywords: \\
Environment, \\
Environmental \\
consciousness, \\
Environmental \\
problems, \\
University \\
students
\end{tabular}

\section{GíRiş}

\section{ABSTRACT}

This research aims to examine the environmental consciousness of university students studying in Ondokuz Mayis University faculty of art and sciences, faculty of education and Kavak vocational high school with various dimensions (gender, program of study, number of ceompleted environmental courses and place of mostly lived). In accordance with this purpose; the study was conducted according to the survey model of quantitative research methods. The working group of the study constitutes a total of 383 university students, 234 female and 149 male, who have taken courses or courses related to environmental and environmental problems and volunteered to participate in the study. The data of this study is gathered through "Personal Information Form" and "The Environmental Attitudes Inventory" developed by Milfont and Duckitt (2006) and adapted to Turkish by Ak (2008). Data collected with the Environmental Attitudes Inventory were transferred to the data analysis package program. In the analysis of the data, independent sample t-test was used when differences were determined according to the number of environmental lessons they took in gender and university; variance analysis (ANOVA) was applied when the differences were determined according to the programs they had studied and the places where most of their lives passed. Research results; indicate that the environmental consciousness scores of female students are significantly higher than male students according to the gender of university students. However, environmental consciousness of university students does not show any significant difference according to the program they have studied. Another finding obtained from the study is that the environmental consciousness of university students is not affected by the fact that they spent most of their lives in the village, district, city or metropolitan area. In addition, according to the result of the research, the number of courses that university students have taken about the environment has reached the conclusion that they do not affect their environmental consciousness. According to these results, it can be said that it is necessary to carry out in-depth studies on the context of the environmental courses given in higher education.

İlkel kabilelerden modern toplumlara kadar insan, doğa ile sürekli etkileşim halinde olmuştur. İnsanların dış dünyası onların beslenme, barınma gibi en temel ihtiyaçlarını nasıl gidereceklerini şekillendirdiği için, insan ve etrafındaki her şey onun yaşama alanını düzenlemiştir. Bununla birlikte insanın çevre ile olan etkileşimi, toplumdan topluma ve bölgeden bölgeye farklılık göstermektedir. Bu nedenle çevre, her insan için farklı bir anlam ifade etmektedir. Çevre, canlı ve cansız varlıkların içinde bulunduğu, belirli bir coğrafi alan oluşturan ve yeryüzünü kuşatan doğal bir fenomendir. İnsanın veya herhangi bir canlının yaşadığı ortam olarak tanımlanan çevre, canlı varlıkları kendisine yaşamsal bağlarla bağlayan, onları etkileyen ve onlardan farklı yollarla etkilenen bir ortamdır (Güney, 2004: 156; Özey, 2001:17). Coğrafi anlamda ise yeryüzü ya da Dünya ekosisteminin sınırları içerisinde kalan bu mekan (Doğanay, 1993:7) aynı zamanda tüm canlıların hayatları boyunca karşılıklı olarak etkileşim halinde oldukları; sosyal, ekonomik, kültürel ve biyolojik faaliyetlerinin tamamını devam ettirdikleri bir 
ortamdır (Seçgin vd., 2010). Çevre, insan faaliyetleri ile birlikte düşünülmelidir. Çünkü çevre, sadece insan dışında kalan dış dünya değil, insanlar tarafından değiştirilip biçimlendirilen bir yerdir. Çevre aynı zamanda dış dünyanın, insanın iç dünyasıyla bütünleştirildiği, insanın kendisini ait hissettiği bir ortamdır.

İnsanın çevreye hükmetme çabası, çevreyi kendi çıkarları doğrultusunda kullanma isteği ve çevreden maksimum düzeyde faydalanma arzusu, çevre sorunlarının ortaya çıkmasına neden olmuştur. İnsanların çevre üzerindeki olumsuz etkileri ve doğal kaynakların tükenebileceğinin bilinçsizce kullanımı, çevrede meydana gelen sorunları daha büyük boyutlara taşımış ve bu durumdan hayati derecede zarar gören yine insan olmuştur. Çevre sorunlarl; insanların meydana getirdiği yapay çevrenin doğal çevre üzerindeki olumsuz etkileri, çevrenin canlıların sağlıklı yaşam şartlarına uygun olmaması, tabii kaynakların aşırı ve yanlış kullanımı ve çevrenin tahrip edilmesi sonucunda ortaya çıkan sorunlardır (Özer, 1993: 2). Çevre sorunları aynı zamanda, Dünyadaki canlı ve cansız tüm varlıkların sürdürülebilir bir yaşam sağlayamaması durumu ve kaynakların bilinçsiz kullanılmasıyla hava, su ve topraktaki kirlenmenin doğal çevre üzerinde oluşturduğu bozulma olarak da tanımlanmaktadır (Titiz, 1995; Kahyaoğlu ve Özgen, 2012). Bütün bu çevre sorunlarının temelinde ise insan kaynaklı yanlış uygulamalar yatmaktadır. Bu nedenle çevre sorunlarının ortaya çıkmasında en büyük etkiye sahip olan aktörün yani insanın, çevre bilincinin geliştirilmesi gerekmektedir. Dünyanın taşıma kapasitesinin ötesine geçildiği ve gezegensel sınırlara yaklaşıldığı (Pengra, 2012: 6) düşünüldüğünde tüm paydaşlar, insan ve çevre ilişkisine güçlü bir mekânsal perspektiften bakarak, küresel ve yerel çevre sorunlarının çözümüne odaklanmalıdır. Çevre eğitimi ise, bu sorunların nedenlerinin anlaşılması ve yeni çevresel sorunların ortaya çıkmaması için en geçerli yollardan biridir.

Çevresel tutum ya da duyarlılıklar; bireylerin aldığı çevre eğitimi, okudukları bölümler, cinsiyet, yaşamını sürdürdüğü yer, teknoloji kullanımına açık olmak gibi değişkenlere göre farklılık göstermektedir. Çevresel tutum ve duyarlılıklar konusunda farklı görüşler olmasına rağmen, çevre konusunda yapılan çalışmaların merkezinde çevre eğitimi bulunmaktadır (Gülay ve Ekici, 2010; Şimşekli, 2004; Uzun ve Sağlam, 2007; Ünal ve Dımışlı, 1999).

Alanyazında çevresel tutum ve duyarlılığın yaş ve sınıf düzeyine göre değişiklik gösterdiğine yönelik bazı çalışmalar bulunmaktadır. Akbaş (2007) çalışmasında, fen bilgisi öğretmen adaylarının çevre duyarlılıklarının sınıf düzeyine göre değiştiği ve son sınıfta okuyan öğretmen adaylarının çevre duyarlılıklarının, birinci sınıfta okuyanlara göre daha yüksek olduğu sonucuna ulaşmıştır (Akbaş, 2007:56). Oweini ve Houri (2006) tarafından Lübnanlı üniversite öğrencilerinin çevre tutumlarını ve bilgilerini belirlemeyi amaçlayan çalışmada ise öğrencilerin tutum puanları yüksek bulunmasına rağmen, çevre ile ilgili konularda harekete geçme isteği ve davranış puanlarının düşük olduğu belirlenmiştir. Kahyaoğlu ve Özgen'in çalışmasında (2012) öğretmen adaylarının çevre sorunlarına yönelik tutumlarının orta düzeyde ve olumlu olduğu tespit edilmiştir. Buna karşın Erol ve Gezer (2006), üniversite öğrencilerinin çevre ve çevre sorunlarına yönelik tutumlarının zayıf olduğunu belirtmişlerdir. Atasoy ve Ertürk (2008), ilköğretim öğrencilerinin çevre ve çevre sorunları konusunda yetersiz olduklarını vurgulamışlardır. Benzer şekilde Şama (2003), üniversite öğrencilerinin çevreye yönelik tutumlarının düşük olduğunu bulmuştur.

Öğrencilerin çevresel tutum ve farkındalıklarında cinsiyetin önemli bir değişken olduğunu inceleyen çalışmalar bulunmaktadır. Çelen ve diğerleri (2002) tarafından üniversite öğrencileri ile yürütülen çalışmada, kız öğrencilerin erkek öğrencilere göre çevre duyarlılıklarının yüksek olduğu, çevre kirliliğini en önemli çevre sorunu olarak gördükleri sonuçlarına ulaşılmıştır. Atasoy'un (2005) ortaokul öğrencileri ile yürüttüğü çalışmanın sonuçlarına göre de, kız 
öğrencilerin çevre tutumları erkek öğrencilere göre daha yüksektir (Atasoy, 2005: 318). O'Brien'ın (2007) çalışmasında ise öğrencilerin çevreye yönelik bilgi seviyesinin orta düzeyde olduğu, yaşı büyük olan üniversite öğrencilerinin ve erkek öğrencilerin bilgi seviyelerinin daha yüksek olduğu görülmüştür (O’Brien, 2007:86). Aynı çalışmada öğrencilerin çoğunun orta ve yüksek düzeyde tutum puanlarına sahip olduğu, ancak kız öğrencilerin tutum puanlarının erkek öğrencilere göre fazla olduğu ortaya konulmuştur. Çimen (2008) ise benzer şekilde öğretmen adayları ile yürüttüğü çalışmada, kadın öğretmen adaylarının çevre tutumlarının erkeklere göre daha yüksek olduğu sonucuna ulaşmıştır (Çimen, 2008:46). Lise öğrencileri ile yürütülen bir başka çalışmada da cinsiyet açısından çevre tutumları arasında kız öğrenciler lehine anlamlı farklılık olduğu tespit edilmiştir (Uzun, 2007:58). Bu çalışmalarla benzer şekilde, Kahyaoğlu ve Özgen (2012) de eğitim fakültesinde okuyan kız öğrencilerin erkeklere göre daha yüksek çevre tutumlarına sahip olduğunu belirtmektedir.

Alanyazında, üniversite öğrencilerinin eğitim aldıkları bölümler ve çevresel tutumları arasındaki ilişkiyi inceleyen çalışmaların da yapıldığı görülmektedir. Talay ve diğerlerinin (2004) çalışmalarında, lisans öğrencilerinin makul bir çevre bilinç düzeyine sahip oldukları ve sağlık bilimleri programlarında okuyan öğrencilerin diğer öğrencilere göre çevresel sorunlara yönelik farkındalıklarının daha yüksek olduğu sonuçları elde edilmiştir. Oğuz ve diğerlerinin (2011) Ankara'da Peyzaj Mimarlığı, Çevre Mühendisliği ve Şehir ve Bölge Planlama lisans programlarında öğrenim gören öğrencilerin çevre ile ilgili konularda farkındalık, bilinç ve duyarlılık seviyelerinin belirlenmesinin amaçlandığı çalışmada; çevre ile ilgili konularda farkındalık ve duyarlılık seviyesinin öğrencilerin okudukları sınıf düzeylerinden bağımsız olduğu ve çevresel sorunlar ve kaynakların korunması konusunda kavramsal olarak bilgi sahibi olsalar da gündelik yaşamlarında tutum ve davranış biçimlerinin aynı seviyede olmadığı tespit edilmiştir. Kaplowitz ve Levine (2005) tarafından Michigan State Üniversitesi öğrencilerinin çevre bilgisini ölçmek amacıyla yaptıkları çalışmada elde edilen sonuçlara göre; tıp, doğa bilimleri, veterinerlik ve ziraat fakülteleri öğrencilerinin bilgi düzeyleri işletme, insan ekolojisi, eğitim ve hemşirelik fakültelerindeki öğrencilere göre daha yüksek bulunmuştur. Ak'ın (2008) çalışmasında eğitim fakültelerinin ilköğretim bölümündeki anabilim dallarında öğrenim gören öğretmen adaylarının çevre bilinçleri araştırılmıştır. Çalışmanın bulgularına göre, çevre dersi almayan öğretmen adaylarının çevre ile ilgili ders alanlara göre beklenenin aksine daha yüksek çevre bilincine sahip oldukları sonucu ortaya çıkmıştır. Çimen (2008) ise öğretmen adayları ile yürüttüğü çalışmada öğrencilerin çevre tutumlarının, bölümlerine ve sınıf seviyelerine göre farklılaşmadığı sonucuna ulaşmıştır (Çimen, 2008:61).

Çevresel tutum üzerinde bireyin yaşamını sürdürdüğü ya da çocukluğunun nasıl bir çevresel ortamda geçtiği önemli bir değişken iken, alanyazında konuyla ilgili fazla bir çalışma bulunmamaktadır. Straughan ve Robert (1999) tarafından yapılan çalışmada, şehirde yaşayanların kırsal kesimde yaşayanlara göre daha fazla çevresel kaygılara sahip olduğu belirtilmiştir. Kahyaoğlu ve Özgen'in (2012) çalışmalarında, köyde yaşayan öğretmen adaylarının tutumlarının büyükşehir, şehir ve kasabada yaşayan öğretmen adaylarının tutumlarına göre daha yüksek ve olumlu olduğu tespit edilmiştir. Bununla birlikte, öğretmen adaylarının en uzun süre ikamet ettikleri yerleşim yeri ile çevre sorunlarına yönelik tutumları arasında istatistiksel olarak anlamlı bir farkın olmadığı tespit edilmiştir. Buna karşın Ek ve diğerleri (2009), farklı programlardaki üniversite öğrencilerinin ikamet ettikleri yere göre çevre sorunlarına yönelik tutumları ve duyarlılıkları üzerine yaptıkları çalışmada, büyükşehirde yaşayan öğrenciler ile köyde yaşayan öğrenciler arasında büyükşehirde yaşayan öğrenciler lehine anlamlı bir fark olduğu sonucunu elde etmişlerdir. Benzer şekilde Şama (2003), üniversite 
öğrencilerinin en uzun süre yaşadıkları yerleşim yeri ile çevresel tutumları arasındaki ilişkinin büyükşehirde yaşayanların lehine anlamlı olduğunu belirtmiştir.

Çevre eğitimi dersini alan öğrencilerin çevresel sorumluluk duygularının gelişmesi ve çevre merkezli bir tutuma sahip olmaları beklenmektedir. Bu çalışmada okudukları lisans programları kapsamında çevre dersi ya da dersleri alan üniversite öğrencilerinin çevre bilinçlerinin belirlenmesi amaçlanmıştır. Üniversite öğrencilerinin çevre tutum ve bilinçlerinin; cinsiyet, bölüm, hayatın büyük bölümünün geçtiği yerleşim birimi ve çevreyle ilgili aldıkları ders sayısı boyutları ile incelenmesi hedeflenmiştir. Alanyazında farklı eğitim düzeylerinde ve çeşitli boyutlarda yapılan çalışmalar mevcuttur. Çevre dersi alan ve almayan öğrencilerle ilgili çalışmalara da rastlanılmaktadır ancak sadece çevre ile ilgili ders ya da dersleri alan üniversite öğrencileri ile yapılan bir araştırma bulunmamaktadır. Araştırma bu boyutuyla, alınan çevre dersi sayısı ile çevre bilinci arasındaki durumu ortaya koyması bakımından diğer araştırmalardan ayrılmaktadır. Bu araştırmayı diğerlerinden ayıran bir başka nokta ise Ondokuz Mayıs Üniversitesi örneğinde yürütülmesi ve çalışmanın güncel olmasıdır. Bu sayede geçmişte ve günümüzde yapılan araştırmaların değişimini kıyaslamak da mümkün olacaktır. Araştırma ile üniversite öğrencilerinin çevre bilinçlerinin gelişmesinde çevre eğitiminin rolünün tespit edilmesi, farklı fakülte ve yüksekokullarda öğrenim gören öğrencilerin çevre bilinçlerinin incelenmesi ve özellikle de üniversitelerde yer alan çevre dersleri ile ilgili önemli sonuçlara ulaşılacağı düşünülmektedir.

\section{YÖNTEM}

Üniversite öğrencilerinin çevre bilinçlerini çeşitli boyutlarla incelemeyi amaçlayan bu çalışmada, nicel araştırma yöntemlerinden tarama modeli kullanılmıştır. Tarama araştırmalarında, bir durumu etkileme ve değiştirme amacı gütmeden betimlemek esastır ve araştırma konusu olan durum, olay ya da birey kendi koşulları dahilinde ve olduğu haliyle tanımlanır (Karasar, 2014:7). Araştırmada; üniversitede çeşitli lisans ve ön lisans programlarında öğrenim gören öğrencilerin çevre bilinçleri, değiştirme veya etkileme amacı olmadan incelendiği için bu yöntem tercih edilmiştir. Bu çalışma, betimlenen boyutların tek seferde ölçülmesi özelliğini taşıdığından aynı zamanda bir kesitsel tarama araştırmasıdır (Büyüköztürk vd., 2016:179).

\section{Çalışma Grubu}

Araştırmanın çalışma grubunu, "Ondokuz Mayıs Üniversitesi" nde öğrenim gören, çevre dersi almış olan ve çalışmaya katılmaya gönüllü olan 383 öğrenci oluşturmaktadır. Çalışma grubu belirlenirken üniversitede çevreyle ilgili derslerin verildiği bölümler ve onların altındaki anabilim dalları ve programlar belirlenmiştir. Daha sonra seçkisiz örnekleme yöntemiyle bu bölümlerde öğrenim gören öğrenciler araştırmaya katılmıştır. Seçkisizlik (yansızlık), örneklemede temel alınan birimlerin örneklem için seçilme olasılıklarının eşit olmasını sağlar. Seçilme olasılıklarının eşit olması, evren değerlerinin daha güçlü tahmin edilebilmesini sağlar (Büyüköztürk vd., 2016:83). Bu araştırmada, evren değerlerinin daha güçlü tahmin edilebilmesini sağlamak amacıyla bu örnekleme yöntemi tercih edilmiştir. Araştırmada; Fen Edebiyat Fakültesi'nde öğrenim Coğrafya Bölümü öğrencileri ve Eğitim Fakültesi'nden seçilen Sosyal Bilgiler Öğretmenliği, Okul Öncesi Öğretmenliği, Sınıf Öğretmenliği programları ile meslek yüksekokullarından seçilen Harita ve Kadastro ile Mimari Restorasyon programlarına kayıtlı toplam 383 öğrenci yer almıştır. Öğrencilerin bu programlardan seçilmesinin nedeni, bu programların üniversitede çevre ile ilgili derslerin yer aldığı programlar olmasıdır. Katılımcıların 
$234^{\prime}$ ü kadın (\%61), 149’u (\%39) ise erkektir. Değişkenlere göre çalışma grubu ile ilgili istatistiki bilgiler Tablo 1'de yer almaktadır.

Tablo 1. Çalışma Grubunun Değişkenlere Göre Dağılımı

\begin{tabular}{llcc}
\hline \multicolumn{1}{c}{ Değişkenler } & & $\mathrm{f}$ & $\%$ \\
\hline \multirow{3}{*}{ Cinsiyet } & Kadın & 234 & 61,1 \\
& Erkek & 149 & 38,9 \\
& Toplam & 383 & 100,0 \\
\cline { 2 - 4 } & Sosyal Bilgiler Öğretmenliği & 60 & 15,7 \\
& Okul Öncesi Öğretmenliği & 32 & 8,4 \\
Program & Sinıf Öğretmenliği & 91 & 23,8 \\
& Coğrafya & 114 & 29,8 \\
& Mimari Restorasyon & 38 & 9,9 \\
& Harita ve Kadastro & 48 & 12,5 \\
& Toplam & 383 & 100,0 \\
\cline { 2 - 5 } Hayatın Büyük Bölümünün & Köy & 68 & 17,8 \\
Geçtiği Yerleşim Birimi & İlçe & 104 & 27,3 \\
& Şehir & 99 & 26,0 \\
& Büyükşehir & 110 & 28,9 \\
& Toplam & 381 & 100,0 \\
\cline { 2 - 4 } & 1 & 221 & 60,2 \\
Aldığ1 Çevre Dersi & 2 ve üstü & 146 & 39,8 \\
& Toplam & 367 & 100,0 \\
\hline
\end{tabular}

\section{Veri Toplama Araçları}

Çalışmanın verileri; araştırmacılar tarafından oluşturulan "Kişisel Bilgi Formu" ve Milfont ve Duckitt (2006) tarafından geliştirilen "The Environmental Attitudes Inventory" ve Ak (2008:65) tarafından Türkçeye uyarlanan "Çevre Bilinci Ölçeği" kullanılarak toplanmıştır.

Araştırmada kullanılan kişisel bilgi formu öğrencilerin; cinsiyetleri, hayatlarının büyük bölümünü geçirdikleri yerleşim birimi, öğrenim gördükleri program ve çevre ile ilgili aldıkları ders sayılarına ait bilgileri içeren bölümlerden oluşmaktadır.

Çalışmanın diğer veri toplama aracı olan ve orijinali 12 boyuttan oluşan Çevre Bilinci Ölçeği, Ak (2008) tarafından yapılan çalışma ile Türkçeye uyarlanıp uygulandıktan sonra yapılan faktör analizi sonucunda, toplam 53 madde olarak son halini alarak "Doğanın Tadı", "Çevresel Eylemler", "Çevresel Tehdit", "İnsanların Doğadan Faydalanması", "Bilim ve Teknolojiye Güven" ve "Nüfus Artışı Politikalarına Destek" olmak üzere altı alt boyuttan oluşmaktadır. Ölçeğin alt boyutlarının güvenilirlik katsayıları sırasıyla; $0.87,0.85,0.69,0.80,0.82$ ve 0.76 olarak bulunmuştur (Ak, 2008:64). Karataş (2013:193) ise tüm ölçeğin güvenilirlik katsayısını 0.87 olarak hesaplamıştır. 7'li derecelendirme tipi ölçek 1'den (kesinlikle katılmıyorum) başlayarak 7'ye (kesinlikle katıllyorum) kadar derecelendirilmiştir. Maddelerin derecelerinin puanlanmasında olumsuzdan olumluya doğru puanlama, 1'den 7 sayısına doğru yapılmıştır. Ölçekteki puan aralığ1 1 ile 7 arasında olduğundan, puanlar 7'ye yaklaştıkça öğrencilerin çevre bilinçlerinin yüksek, 1'e yaklaştıkça düşük olduğu kabul edilmiştir.

\section{Verilerin Analizi}

Çevre Bilinci Ölçeği ile toplanan veriler veri analizi paket programına girilmiştir. Veri setinde eksik ve yanlış verilerin olup olmadığı frekans analizi ile tespit edilerek gerekli düzenlemelerle veriler analiz için uygun hale getirilmiştir. Likert tipteki ölçeğin maddeleri hem olumlu hem de olumsuz anlama sahip olduklarından, olumsuz anlamı olan maddeler ters 
olacak şekilde kodlanmıştır. Verilerin analizinde cinsiyete ve üniversitede aldıkları çevre dersi sayılarına göre farklılıklar belirlenirken, "bağımsız örneklem t-testi", öğrenim gördükleri programlara ve hayatlarının büyük bölümünün geçtiği yerlere göre farklılıklar belirlenirken "varyans analizi (ANOVA)" uygulanmıştır.

\section{BULGULAR}

Üniversite öğrencilerinin çevre bilinçlerini incelemeyi amaçlayan bu araştırmada Çevre Bilinci Ölçeği ile toplanan veriler analiz edilmiştir. Analiz sonucunda elde edilen bulgulara bakıldığında; üniversite öğrencilerinin Çevre Bilinci Ölçeği'nin genelinden ve alt boyutlarından aldıkları puanlara ilişkin betimleyici istatistikler Tablo 2' de görülmektedir.

Tablo 2. Üniversite Öğrencilerinin Çevre Bilinci Ölçeği'nin Geneli ve Alt Boyutlarından Aldıkları Puanlara İlişkin Betimleyici İstatistikler

\begin{tabular}{lccc}
\hline \multicolumn{1}{c}{ Alt Boyutlar } & $\mathbf{N}$ & $\overline{\mathbf{X}}$ & SS \\
\hline Doğanın Tadı & 383 & 5,25 & 0,84 \\
Çevresel Eylemler & 383 & 5,20 & 1,14 \\
Çevresel Tehdit & 383 & 5,65 & $\mathbf{1 , 1 3}$ \\
İnsanların Doğadan Faydalanması & 383 & 5,56 & 1,19 \\
Bilim ve Teknolojiye Güven & 383 & 3,77 & $\mathbf{1 , 0 0}$ \\
Nüfus Artı̧ı Politikalarına Destek & 383 & 4,25 & $\mathbf{1 , 1 5}$ \\
\hline \multicolumn{1}{c}{ Genel } & $\mathbf{3 8 3}$ & $\mathbf{5 , 0 2}$ & $\mathbf{0 , 6 6}$ \\
\hline
\end{tabular}

Puanların ortalamalarına bakıldığında öğrencilerin en yüksek puanı 5,65 ile "Çevresel Tehdit" boyutundan aldığı görülmektedir. Daha sonra onu 5,56 ortalamayla "İnsanların Doğadan Faydalanması" boyutu izlemektedir. Öğrenciler en düşük puanı ise 3,77 ortalamayla "Bilim ve Teknolojiye Güven" boyutundan almışlardır. Testin geneline bakıldığında ise öğrencilerin ortalama puanları 5,02 olmuştur. Bu da üniversite öğrencilerinin çevreye yönelik bilinçlerinin ortalamanın üstünde olduğunu göstermektedir.

Üniversitede çevreyle ilgili ders almış öğrencilerin cinsiyetlerine göre "Doğanın Tadı", "Çevresel Eylemler", "Çevresel Tehdit", "İnsanların Doğadan Faydalanması", "Bilim ve Teknolojiye Güven" ve "Nüfus Artışı Politikalarına Destek" alt boyutlarından aldıkları puanlar arasındaki farkı belirlemek için bağımsız örneklem t-testi yapılmıştır. Test sonuçları Tablo 3 'te yer almaktadır. 
Tablo 3. Üniversite Öğrencilerinin Çevre Bilinci Ölçeği'nin Alt Boyutlarından Aldıkları Puanların Cinsiyete Göre Karşılaştırılmasına İlişkin Bağımsız Örneklem T-Testi Sonuçları

\begin{tabular}{lccccccc}
\hline \multicolumn{1}{c}{ Alt Boyutlar } & Grup & $\mathbf{N}$ & $\overline{\mathbf{X}}$ & $\mathbf{S S}$ & $\mathbf{s d}$ & $\mathbf{t}$ & $\mathbf{p}$ \\
\hline \multirow{2}{*}{ Doğanın Tadı } & Kadın & 234 & 5,27 & 0,89 & 381 & 0,65 & 0,514 \\
& Erkek & 149 & 5,21 & 0,75 & & & \\
Çevresel Eylemler & Kadın & 234 & 5,39 & 1,07 & 381 & 4,16 & 0,000 \\
& Erkek & 149 & 4,90 & 1,20 & & & \\
Çevresel Tehdit & Kadın & 234 & 5,71 & 1,18 & 381 & 1,27 & 0,203 \\
& Erkek & 149 & 5,56 & 1,05 & & & \\
İnsanların Doğadan Faydalanması & Kadın & 234 & 5,64 & 1,27 & 381 & 1,73 & 0,083 \\
& Erkek & 149 & 5,43 & 1,04 & & & \\
Bilim ve Teknolojiye Güven & Kadın & 234 & 3,91 & 1,05 & 381 & 3,57 & 0,000 \\
& Erkek & 149 & 3,54 & 0,87 & & & \\
\multirow{3}{*}{ Nüfus Artışı Politikalarına Destek } & Kadın & 234 & 4,35 & 1,11 & 381 & 2,14 & 0,033 \\
& Erkek & 149 & 4,09 & 1,19 & & & \\
\hline \multirow{2}{*}{ Genel } & Kadın & 234 & 5,11 & 0,70 & 381 & 3,72 & 0,000 \\
& Erkek & 149 & 4,87 & 0,54 & & & \\
\hline
\end{tabular}

Test sonucuna göre, üniversite öğrencilerinin cinsiyetlerine göre "Çevresel Eylemler" bölümünden aldıkları puanlar arasında anlamlı bir fark olduğu söylenebilir (t(381) =4,16; $\mathrm{p}<$ 0,01). Kadın öğrenciler $(X=5,39)$ çevresel eylemler konusunda erkek öğrencilere $(X=4,90)$ göre daha duyarlıdır. Öğrencilerin cinsiyetlerine göre "Bilim ve Teknolojiye Güven" bölümünden aldıkları puanlar arasında da anlamlı bir fark olduğu söylenebilir $(t(381)=3,57 ; p<0,01)$. Kadın öğrenciler $(X=3,91)$, erkek öğrencilere göre $(X=3,54)$ bilim ve teknolojiye güven konusunda daha fazla çevre bilincine sahip olduğu söylenebilir. Öğrencilerin "Nüfus Artışı Politikalarına Destek" bölümlerinden aldıkları puanlar da cinsiyetlerine göre farklılık göstermektedir $(\mathrm{t}(381)=2,14$; $\mathrm{p}<$ 0,05). Kadın öğrencilerin ortalaması 4,35, erkek öğrencilerin ortalama puanı olan 4,09'a göre nüfus artışı konusunda daha fazla çevre bilincine sahip olduğu görülmektedir. Bir başka ifadeyle kadın öğrenciler nüfus artışının çevre üzerindeki etkilerini, erkek öğrencilere göre daha fazla önemsemektedirler.

Ancak çalışmaya katılan öğrencilerin "Doğanın Tadı", "Çevresel Tehdit" ve "İnsanların Doğadan Faydalanması" bölümlerinden aldıkları puanlar arasında anlamlı bir fark bulunmamıştır. Ayrıca Çevre Bilinci Ölçeği'nin geneline göre üniversite öğrencilerinin çevre bilinci, cinsiyetlerine göre farklılık göstermektedir ( $((381)=3,72 ; \mathrm{p}<0,01)$. Kadın öğrenciler $(X=$ $5,11)$, erkek öğrencilere $(X=4,87)$ göre daha fazla çevre bilincine sahiptir.

Üniversite öğrencilerinin okudukları bölümlere göre "Doğanın Tadı", "Çevresel Eylemler", "Çevresel Tehdit", "İnsanların Doğadan Faydalanması", "Bilim ve Teknolojiye Güven" ve "Nüfus Artışı Politikalarına Destek" alt boyutlarından aldıkları puanlar arasında fark olup olmadığını bulmak için varyans analizi yapılmıştır. Varyans analizi sonuçları Tablo 4'te yer almaktadır. 
Tablo 4. Üniversite Öğrencilerinin Çevre Bilinci Ölçeği'nin Alt Boyutlarından Aldıkları Puanların Öğrenim Gördükleri Bölümlere Göre Karşılaştırılmasına İlişkin Tek Yönlü Varyans Analizi Sonuçları

\begin{tabular}{llccccc}
\hline \multicolumn{1}{c}{ Varyansın Kaynağı } & & KT & sd & KO & F & p \\
\hline \multirow{3}{*}{ Doğanın Tadı } & Gruplar arası & 2,080 & 5 & 0,41 & 0,59 & 0,707 \\
& Grup içi & 265,222 & 377 & 0,70 & & \\
& Toplam & 267,302 & 382 & & & \\
Çevresel Eylemler & Gruplar arası & 6,790 & 5 & 1,35 & 1,03 & 0,394 \\
& Grup içi & 492,556 & 377 & 1,30 & & \\
& Toplam & 499,346 & 382 & & & \\
Çevresel Tehdit & Gruplar arası & 9,087 & 5 & 1,81 & 1,42 & 0,216 \\
& Grup içi & 482,649 & 377 & 1,28 & & \\
İnsanların Doğadan Faydalanması & Goplam & 491,736 & 382 & & & \\
& Gruplar arası & 4,671 & 5 & 0,93 & 0,65 & 0,654 \\
& Toplam & 534,084 & 377 & 1,41 & & \\
Bilim ve Teknolojiye Güven & 538,755 & 382 & & & \\
& Gruplar arası & 6,577 & 5 & 1,31 & 1,32 & 0,254 \\
& Grup içi & 375,381 & 377 & 0,996 & & \\
& Toplam & 381,958 & 382 & & & \multirow{2}{*}{ Nün } \\
& Gruplar arası & 17,055 & 5 & 3,41 & 2,64 & 0,023 \\
& Grup içi & 486,679 & 377 & 1,29 & & \\
& Toplam & 503,733 & 382 & & & \\
\hline \multirow{2}{*}{ Genfus Artışı Politikalarına Destek } & Gruplar arası & 2,558 & 5 & 0,51 & 1,19 & 0,312 \\
& Grup içi & 161,725 & 377 & 0,42 & & \\
& Toplam & 164,283 & 382 & & & \\
\hline
\end{tabular}

Analiz sonucunda, üniversite öğrencilerinin "Nüfus Artışı Politikalarına Destek" bölümünden aldıkları puanların okudukları bölümlere göre farklılık gösterdiği bulunmuştur $(\mathrm{F}(5,37)=2,64 ; \mathrm{p}<0,05) . \quad B u$ farklılıkların hangi bölümler arasında olduğunu belirlemek için öncelikle varyansların homojen dağılıp dağılmadığını görmek için Levene testi yapılmış, test sonucunda da varyansların homojen dağıldığı görülmüştür $(p>0,05)$. Bu nedenle Tukey testi kullanılmıştır. Ancak Tukey testi sonucunda bölümler arasında herhangi bir fark bulunamamıştır.

Varyans analizi sonucu, üniversite öğrencilerinin "Doğanın Tadı”, “Çevresel Eylemler”, "Çevresel Tehdit", "İnsanların Doğadan Faydalanması" ve "Bilim ve Teknolojiye Güven" alt boyutlarından aldıkları puanlar arasında, öğrenim gördükleri bölümlere göre de fark olmadığını göstermektedir.

Üniversite öğrencilerinin hayatlarının büyük bölümünün geçtiği yere göre "Doğanın Tadı", "Çevresel Eylemler", "Çevresel Tehdit", "İnsanların Doğadan Faydalanması", "Bilim ve Teknolojiye Güven" ve "Nüfus Artışı Politikalarına Destek" alt boyutlarından aldıkları puanlar arasındaki farkı belirlemek amacıyla varyans analizi yapılmıştır. Analiz sonuçları Tablo 5'te yer almaktadir. 
Tablo 5. Üniversite Öğrencilerinin Çevre Bilinci Ölçeği'nin Alt Boyutlarından Aldıkları Puanların Yerleşim Birimine Göre Karşılaştırılmasına İlişkin Varyans Analizi Sonuçları

\begin{tabular}{|c|c|c|c|c|c|c|}
\hline Varyansın Kaynağı & & KT & SD & KO & $\mathbf{F}$ & p \\
\hline & Gruplar arası & 1,035 & 3 & 0,34 & 0,49 & 0,688 \\
\hline \multirow[t]{3}{*}{ Doğanın Tadı } & Grup içi & 264,610 & 377 & 0,70 & & \\
\hline & Toplam & 265,645 & 380 & & & \\
\hline & Gruplar arası & 1,168 & 3 & 0,38 & 0,29 & 0,827 \\
\hline \multirow[t]{3}{*}{ Çevresel Eylemler } & Grup içi & 493,968 & 377 & 1,31 & & \\
\hline & Toplam & 495,136 & 380 & & & \\
\hline & Gruplar arası & 5,927 & 3 & 1,97 & 1,54 & 0,203 \\
\hline \multirow[t]{3}{*}{ Çevresel Tehdit } & Grup içi & 482,522 & 377 & 1,28 & & \\
\hline & Toplam & 488,448 & 380 & & & \\
\hline & Gruplar arası & 6,248 & 3 & 2,08 & 1,47 & 0,220 \\
\hline \multirow[t]{3}{*}{ İnsanların Doğadan Faydalanması } & Grup içi & 531,037 & 377 & 1,40 & & \\
\hline & Toplam & 537,285 & 380 & & & \\
\hline & Gruplar arası & 2,435 & 3 & 0,81 & 0,81 & 0,489 \\
\hline \multirow[t]{3}{*}{ Bilim ve Teknolojiye Güven } & Grup içi & 377,905 & 377 & 1,002 & & \\
\hline & Toplam & 380,340 & 380 & & & \\
\hline & Gruplar arası & 0,358 & 3 & 0,11 & 0,09 & 0,965 \\
\hline \multirow[t]{3}{*}{ Nüfus Artışı Politikalarına Destek } & Grup içi & 491,831 & 377 & 1,30 & & \\
\hline & Toplam & 492,189 & 380 & & & \\
\hline & Gruplar arası & 1,299 & 3 & 0,43 & 1,00 & 0,390 \\
\hline \multirow[t]{2}{*}{ Genel } & Grup içi & 162,350 & 377 & 0,43 & & \\
\hline & Toplam & 163,650 & 380 & & & \\
\hline
\end{tabular}

Analiz sonucunda, üniversite öğrencilerinin Çevre Bilinci Ölçeği'nin tüm alt bölümlerinden aldıkları puanların, hayatlarının büyük bölümünün geçtiği yere göre anlamlı bir fark oluşturmadığı görülmüştür. Dolayısıyla üniversite öğrencilerinin çevre bilinçlerinin, hayatlarının büyük bir bölümünü köyde, ilçede, şehirde ya da büyükşehirde geçirmiş olmalarından etkilenmediğini söylemek mümkündür.

Üniversite öğrencilerinin çevreyle ilgili aldıkları ders sayılarına göre "Doğanın Tadı", "Çevresel Eylemler", "Çevresel Tehdit", "İnsanların Doğadan Faydalanması", "Bilim ve Teknolojiye Güven" ve "Nüfus Artışı Politikalarına Destek" alt boyutlarından aldıkları puanlar arasındaki farkı belirlemek için bağımsız örneklem t-testi yapılmıştır. Test sonuçları Tablo $6^{\prime}$ da yer almaktadir. 
Tablo 6. Üniversite Öğrencilerinin Çevre Bilinci Ölçeği' nin Alt Boyutlarından Aldıkları Puanların Aldıkları Çevre Dersi Sayısına Göre Karşılaştırılmasına İlişkin Bağımsız Örneklem T-Testi Sonuçları

\begin{tabular}{|c|c|c|c|c|c|c|c|}
\hline Alt Boyutlar & Ders Sayıs1 & $\mathbf{N}$ & $\overline{\mathbf{X}}$ & SS & sd & $\mathbf{t}$ & $\mathbf{p}$ \\
\hline \multirow{2}{*}{ Doğanın Tadı } & 1 & 221 & 5,25 & 0,81 & 365 & $-0,108$ & 0,914 \\
\hline & 2 ve üstü & 146 & 5,25 & 0,87 & & & \\
\hline \multirow{2}{*}{ Çevresel Eylemler } & 1 & 221 & 5,18 & 1,10 & 365 & $-0,309$ & 0,758 \\
\hline & 2 ve üstü & 146 & 5,22 & 1,16 & & & \\
\hline \multirow{2}{*}{ Çevresel Tehdit } & 1 & 221 & 5,70 & 1,05 & 365 & 0,972 & 0,332 \\
\hline & 2 ve üstü & 146 & 5,58 & 1,23 & & & \\
\hline \multirow{2}{*}{ İnsanların Doğadan Faydalanması } & 1 & 221 & 5,56 & 1,16 & 365 & $-0,040$ & 0,968 \\
\hline & 2 ve üstü & 146 & 5,56 & 1,21 & & & \\
\hline \multirow{2}{*}{ Bilim ve Teknolojiye Güven } & 1 & 221 & 3,80 & 1,02 & 365 & 0,763 & 0,446 \\
\hline & 2 ve üstü & 146 & 3,71 & 0,98 & & & \\
\hline \multirow{2}{*}{ Nüfus Artışı Politikalarına Destek } & 1 & 221 & 4,21 & 1,22 & 365 & $-1,034$ & 0,302 \\
\hline & 2 ve üstü & 146 & 4,33 & 1,06 & & & \\
\hline \multirow{2}{*}{ Genel } & 1 & 221 & 5,02 & 0,60 & 365 & 0,160 & 0,901 \\
\hline & 2 ve üstü & 146 & 5,02 & 0,71 & & & \\
\hline
\end{tabular}

Test sonucunda, üniversite öğrencilerinin aldıkları ders sayılarına göre "Doğanın Tadı", "Çevresel Eylemler", “Çevresel Tehdit”, "İnsanların Doğadan Faydalanması”, "Bilim ve Teknolojiye Güven" ve "Nüfus Artışı Politikalarına Destek" alt boyutlarından aldıkları puanlar arasında anlamlı bir farklılık olmadığı görülmüştür. Ayrıca tüm test üzerinden aldıkları puanlar arasında da anlamlı bir fark olmadığı söylenebilir.

\section{TARTIŞMA VE SONUÇ}

Üniversite öğrencilerinin çevre bilinçlerini, onların çevre bilinçlerini etkileyen cinsiyet, öğrenim görülen program, alınan çevre dersi sayısı ve hayatın büyük bölümünün geçtiği yerleşim birimi değşikenlerine göre incelemeyi amaçlayan bu çalışmada, çevre dersi alan üniversite öğrencilerinin çevre bilinç düzeylerinin, ortalama puanın üstünde olduğu sonucuna ulaşılmıştır. Buradan hareketle, çevre eğitimi dersinin öğrencilerin çevreye yönelik bilinç düzeylerini olumlu yönde etkilediği söylenebilir. Küresel anlamda çevre konusunda bilinçlenme sağlanabilmesinde ve çevre bilincinin arttırılmasında çevre eğitiminin önemi tartışlamayacak kadar büyüktür ve çevre eğitimi bir anahtar konumundadır (Wenden, 2004:12; Pandey, 2006:194). Yapılan araştırmalar da çevre eğitimi dersi alan öğrencilerin çevre bilinç düzeylerinin yüksek olduğunu göstermektedir (Karataş, 2013:200; Karpudewan ve İsmail, 2012; Okşaşoğlu, 2006:96). Deniş ve Genç (2007) çevre eğitimi dersi alan sınıf öğretmeni adayları ile bu dersi almayan sınıf öğretmeni adaylarının çevre tutumlarını karşılaştırdıkları çalışmada, çevre eğitimi dersi alan öğretmen adaylarının tutum puanlarının daha yüksek olduğunu belirlemişlerdir. Yine Erdal ve diğerlerinin (2013), içinde öğretmen adaylarının da olduğu farklı bölümlerde okuyan üniversite öğrencilerini kapsayan araştırma sonuçlarına göre de, çevre dersi alan öğrencilerin çevre bilinç puanları yüksek bulunmuştur. Joon ve Kumar'ın (2009) üniversite öğrencileri ile yaptıkları araştırma ise çevre dersi alamayan öğrencilerin normal düzeyde çevre bilincine sahip olduklarını göstermektedir ve bunun çevre dersi ile artırılabileceği vurgulanmaktadır.

Öğrencilerin, Çevre Bilinci Ölçeği'nin alt boyutlarından aldıkları puanların ortalamalarına bakıldığında en yüksek puanların sırasıyla "Çevresel Tehdit" ve "İnsanların Doğadan Faydalanması" boyutlarında olduğu görülmektedir. Üniversite öğrencileri en düşük puanı ise 
"Bilim ve Teknolojiye Güven" boyutundan almışlardır. Sonuçlar, öğrencilerin insanın doğaya müdahalesinin devam etmesi durumunda çok hassas bir dengeye sahip doğanın dengesinin bozulacağ1 ve çok büyük çevresel felaketlerin yaşanacağı kaygısına sahip olduğuna işaret etmektedir. Ayrıca öğrenciler, insanların daha fazla bir ekonomik büyüme için doğaya zarar verdiklerini, doğayı korumanın ekonomik büyümeyi korumaktan daha önemli olduğunu ve insanların doğayı kendi süreklilikleri için tahrip ettiklerini düşünmektedirler.

Ölçekten elde edilen bulgulara göre kadın öğrenciler, erkek öğrencilere göre daha fazla çevre bilincine sahiptir. Buna paralel olarak, Ek ve diğerleri (2009) üniversite öğrencilerinin cinsiyetlerine göre çevre sorunlarına yönelik tutumlarını inceledikleri çalışmada da kadın öğrencilerin erkek öğrencilere göre daha yüksek bir çevre bilincine sahip oldukları tespit edilmiştir. Benzer şekilde, Erol ve Gezer (2006) kızların çevreye yönelik tutumlarının erkeklerin tutum puanlarından daha yüksek olduğunu belirtmişlerdir. Yine Deniş ve Genç (2007) tarafından yapılan çalışmada, kızların çevreye yönelik tutum puanlarının erkeklerin tutum puanlarına göre daha yüksek olduğu belirtilmiştir. Gökçe ve diğerleri (2007), ilköğretim kız öğrencilerinin çevreye yönelik tutum puanlarının erkek öğrencilerin puanlarından daha yüksek olduğunu ortaya koymuşlardır. Straughan ve Robert (1999) tarafından yapılan çalışmada ise, gençlerin çevreye yönelik kaygılara daha duyarlı olduğu, çevre ve çevre sorunlarına kadınların erkeklerden daha ilgili olduğu, eğitim seviyesinin çevresel tutum ve davranışlarla pozitif ilişkisinin olduğu ve şehirde yaşayanların kırsal bölgelerde yaşayanlara göre daha fazla çevresel kaygılara sahip olduğu belirtilmiştir. Sonuçlar çevresel eylemler konusunda kadın öğrencilerin erkek öğrencilere göre daha duyarlı oldukların göstermektedir. Yine bilim ve teknolojiye güven konusunda da kadın öğrenciler daha fazla çevre bilincine sahiplerdir. Ancak öğrencilerin "Doğanın Tadı", "Çevresel Tehdit" ve "İnsanların Doğadan Faydalanması" boyutlarından aldıkları puanlar arasında anlamlı bir fark bulunamamıştır.

Çalışmaya katılan kadın öğrencilerin, erkek öğrencilere göre nüfus artışı konusundaki politikalara daha az destek verdikleri söylenebilir. Bir başka ifadeyle kadın öğrenciler nüfus artışının çevre üzerinde oluşturduğu baskının daha fazla olduğu görüşündedirler. Çevre sorunlarının sebepleri arasında ilk akla gelen nüfus artışıdır. Bu düşünceye göre, çevre sorunlarının oluşumunda başat sebebin nüfustaki artış olduğu, bununla birlikte çevre sorunlarını çözümü için nüfus azaltıcı tedbirlerin gerekliliği, nüfustaki artışın kontrol altına alınmasıyla tüm çevre sorunlarının çözüleceği varsayılır (Varınca, 2011). Ancak unutulmamalıdır ki nüfusun hızlı artması kadar azalması da bir sorundur. Nüfus artışının çevre üzerinde yarattığı sorunların, cinsiyet değişkenine göre incelendiği bir çalışma bulunmamaktadır. Çalışmadan elde edilen bulgulara göre kadın öğrencilerin, nüfus artırıcı politikaları çevre üzerinde baskı unsuru olarak algıladıkları tespit edilmiştir. Nüfusun sürdürülebilir olması için ortalama kadın başına doğurganlık oranının 2,1 olması gerçeği unutulmamalıdır (Nargund, 2009). Bu sonucun kadınlar lehinde yüksek olması doğum ve çocuk yetiştirme sürecinde kadınların karşılaştıkları sorunların ve zorlukların etkisiyle açıklanmaktadır.

Analiz sonuçları, üniversite öğrencilerinin çevre bilinçleri üzerinde öğrenim gördükleri bölümlerin etkisinin olmadığını göstermektedir. Çalışmadan elde edilen sonuçlar ile benzer şekilde, Ankara'da Peyzaj Mimarlığı, Çevre Mühendisliği ve Şehir ve Bölge Planlama lisans programlarında öğrenim gören öğrencilerle yapılan araştırmada da öğrencilerin okudukları bölümün çevreye karşı olan tutum, farkındalık ve duyarlılıkları üzerinde istatistiksel olarak anlamlı bir farklılık bulunmamıştır (Oğuz vd., 2011). Ancak Karataş (2013), yaptığı çalışmada öğrencilerin çevreye yönelik tutumlarında öğrenim gördükleri anabilim dalına göre anlamlı bir 
farklılık olduğunu, bu farklılığın Fen Bilgisi Öğretmenliği anabilim dalında öğrenim gören öğretmen adaylarında Sınıf Öğretmenliği ve Sosyal Bilgiler anabilim dallarına göre daha yüksek olduğunu tespit etmiştir (Karataş, 2013: 211).

Bulgular öğrencilerin çevre bilinci puanlarının tüm alt bölümlerde hayatlarının büyük bir bölümünü geçirdikleri yere göre anlamlı bir fark oluşturmadığını, dolayısıyla üniversite öğrencilerinin çevre bilinci üzerinde, hayatlarının büyük bir bölümünü köyde, ilçede, şehirde ya da büyükşehirde geçirmiş olmalarının etkili olmadığını göstermektedir. Ancak bu sonuç Cici ve diğerleri (2005), ile Karataş (2013) tarafından yapılan çalışmaların sonuçlarıyla uyuşmamaktadır. Zira ilgili araştırmacılar öğrencilerin çevresel farkındalık ve bilgi düzeylerine yönelik olarak yaptıkları araştırmalarda, hayatın büyük bir bölümünün geçtiği yerleşim biriminin çevre bilinci üzerinde etkili olduğu sonucuna ulaşmışlardır. Bu sonuçlar, büyükşehirlerde yaşayanların çevresel farkındalık ve bilgi düzeylerinin diğer yerleşim birimlerinde yaşayanlara göre daha yüksek olduğunu göstermektedir. Yine Yücel ve diğerleri (2006), Adana'da yürüttükleri ve kent halkının çevre duyarlılığı seviyesini belirlemeyi amaçladıkları çalışma sonuçlarına dayanarak, yerleşim birimlerine göre çevresel bilinç ve tutum değerleri arasında farklılık olduğunu, kentlinin çevre duyarlılık düzeyinin "orta" olarak değerlendirildiğini ve eğitim ve gelir seviyesi düştükçe duyarlılık seviyesinin de düştüğünü belirtmişlerdir.

Bu çalışmayı diğer çalışmalardan ayıran özelliklerden biri olan, üniversite öğrencilerinin aldıkları çevre ve çevre sorunlarını içeren ders sayılarına göre, "Doğanın Tadı", "Çevresel Eylemler", "Çevresel Tehdit", "İnsanların Doğadan Faydalanması", "Bilim ve Teknolojiye Güven" ve "Nüfus Artışı Politikalarına Destek" alt boyutlarından aldıkları ve tüm test üzerinden aldıkları puanlar arasında da anlamlı bir fark olmadığı görülmüştür. Köse ve diğerleri (2011) tarafından üniversite öğrencileri üzerinde yapılan araştırma bulguları bu sonuçların aksine çevreyle ilgili aldıkları ders sayısının çevre bilincini arttırdı̆̆ını ortaya koymaktadır. Buna paralel bir şekilde alanyazındaki pek çok çalışma, çevre eğitimiyle öğrencilere çevre bilincinin kazandırılabileceğini savunuyor olmasına rağmen (Arslan, 1997; Çabuk ve Karacaoğlu, 2003; Çakmak ve Akçöltekin, 2012; Eryılmaz ve Kıran, 2017) bu çalışmanın tüm alt boyutlarında öğrencilerin çevreyle ilgili aldıkları ders sayısı ile çevre bilinci düzeyi arasında anlamlı bir farkın olmayışı üniversitelerde okutulan çevre derslerinin niteliğinin sorgulanmasını zaruri kılmaktadır.

Elde edilen sonuçlar ışığında; üniversitelerde verilen çevre ile ilgili derslerin sayısından ziyade niteliğinin önemli olduğu ve bu nedenle bu derslerin hem içerik olarak hem de öğretim yöntemi açısından geliştirilmesi ve güncellenmesi önerilebilir. Çevre ile ilgili derslerin, öğrencilerin çevresel tutum ve bilinçlerini artırdığı görüldüğünden, çevre ile ilgili herhangi bir ders olmayan lisans ve önlisans programlarında bu derslerin yer alması gerektiği düşünülmektedir. Üniversite öğrencilerinin çevre ile ilgili genel olarak olumlu duyuşsal özelliklere sahip oldukları ancak bu durumun davranışa dönüşmesinde güçlükler yaşandığı görülmektedir. Buradan hareketle, çevre ile ilgili derslerin sadece teorik değil "uygulamalı" olarak verilmesi önerilebilir. Son olarak; üniversite öğrencilerinin çevre ile ilgili duyuşsal ve davranışsal özelliklerinin belirlenmesi ve olumlu yönde değiştirilebilmesi için daha kapsamlı akademik çalışmaların yapılması fayda sağlayacaktır. 


\section{KAYNAKÇA}

Ak, S. (2008). İlköğretim öğretmen adaylarını çevreye yönelik bilinçlerinin bazı demografik değişkenler açısından incelenmesi. Yayımlamamış Yüksek Lisans Tezi, Abant İzzet Baysal Üniversitesi Sosyal Bilimler Enstitüsü, Bolu.

Akbaş, T. (2007). Fen bilgisi öğretmen adaylarında çevre olgusunun araştırılması. Yayımlanmamış Yüksek Lisans Tezi, Atatürk Üniversitesi Fen Bilimleri Enstitüsü, Erzurum.

Arslan, M. (1997). Çevre bilincindeki değişimler ve çevre eğitimi. Erişim tarihi: 22.03.2012, http://ekutuphane.egitimsen.org.tr/pdf/108.pdf.

Atasoy, E. (2005). Çevre için eğitim: ilköğretim öğrencilerinin çevresel tutum ve çevre bilgisi üzerine bir çalışma. Yayımlanmamış Doktora Tezi, Uludağ Üniversitesi, Bursa.

Atasoy, E. \& Ertürk, H. (2008). İlköğretim öğrencilerinin çevresel tutum ve çevre bilgisi üzerine bir alan araştırması. Erzincan Eğitim Fakültesi Dergisi, 10(1), 105-122.

Büyüköztürk, Ş., Kılıç-Çakmak, E., Akgün, O.E., Karadeniz, S. \& Demirel, F. (2016). Bilimsel araştırma yöntemleri (22. Baskl). Ankara: Pegem Akademi Yayıncılık.

Cici, M., Şahin, N., Şeker, H., Görgen, İ. \& Deniz, S. (2005). Öğretmen adaylarının katı atık kirliliği bağlamında çevresel farkındalık ve bilgi düzeyleri. Eğitim Bilimleri ve Uygulama, 4(7), 3750.

Çabuk, B. \& Karacaoğlu, C. (2003). Üniversite öğrencilerinin çevre duyarlılıklarının incelenmesi. Ankara Üniversitesi Ĕ̆itim Bilimleri Fakültesi Dergisi, 36(1-2), 189-198.

Çakmak, M. \& Akçöltekin, A. (2012). 8. sınıf öğrencilerinin sera etkisi hakkındaki bilgi düzeylerinin ve kavram yanılgılarının tespit edilmesi. Dicle Üniversitesi Sosyal Bilimler Enstitüsü Dergisi, 4(7), 144-158.

Çelen, Ü., Yıldız, A., Atak, N., Tabak, R. H., \& Arısoy, M. (2002). Ankara üniversitesi sağlık eğitim fakültesi öğrencilerinin çevre duyarlılı̆̆ı ve ilişkili faktörler. 8. Ulusal Halk Sağlığı Kongresi, Diyarbakır.

Çimen, O. (2008). Çevre eğitiminde tatlısu ekosistemleri konusundaki temel kavramlarn üniversite öğrencileri tarafindan algılanma düzeyleri. Yayımlamamış Yüksek Lisans Tezi, Gazi Üniversitesi Eğitim Bilimleri Enstitüsü, Ankara.

Deniş, H. \& Genç, H. (2007). Çevre dersini alan ve almayan sınıf öğretmenliğindeki öğrencilerin çevreye ilişkin tutumları ve çevre bilimi dersindeki başarılarının karşılaştırılması. Mehmet Akif Ersoy Üniversitesi Eğitim Fakültesi Dergisi, (20), 20-26.

Doğanay, H. (1993). Coğrafya'ya giriş. Erzurum: Aktif Yayınları.

Ek, H. N., Kılıç, N., Öğdüm, P., Düzgün, G., \& Şeker, S. (2009). Adnan Menderes Üniversitesinin farklı akademik alanlarında öğrenim gören ilk ve son sını öğrencilerinin çevre sorunlarına yönelik tutumları ve duyarlılıkları. Kastamonu Eğitim Dergisi, 17(1), 125-136.

Erdal, H., Erdal, G. \& Yücel, M. (2013). Üniversite öğrencilerinin çevre bilinç düzeyi araştırması: Gaziosmanpaşa Üniversitesi örneği. Gaziosmanpaşa Bilimsel Araştırma Dergisi, 1(4), 57-65.

Erol, G. H. \& Gezer, K. (2006). Prospective of elementary school teachers' attitudes toward environment and environmental problems. International Journal of Environmental and Science Education, 1(1), 65-77.

Eryılmaz, Ç. \& Kıran, Ö. (2017). Üniversite öğrencilerinin çevre algısı: Sinop Üniversitesi örneği. Akademik Sosyal Araştırmalar Dergisi, 5, (61), 186-199.

Gökçe, N., Kaya, E., Aktay, S., \& Özden, M. (2007). İlköğretim öğrencilerinin çevreye yönelik tutumları. İlköğretim Online Dergisi, 6(3), 452-468. 
Gülay, H., \& Ekici, G. (2010). MEB okul öncesi eğitim programının çevre eğitimi açısından analizi. Türk Fen Eğitimi Dergisi, 7(1), 74-84.

Güney, E. (2004). Çevre sorunları coğrafyası. Ankara: Gündüz Eğitim ve Yayıncılık.

Joon, V., \& Kumar, K. (2009). An assessment of environmental consciousness level of university students of Hisar City. J Hum Ecol., 28(2), 149-151.

Kahyaoğlu, M. \& Özgen, N. (2012). Öğretmen adaylarının çevre sorunlarına yönelik tutumlarının çeşitli değişkenler açısından incelenmesi. Kuramsal Eğitimbilim Dergisi, 5(2), 171-185.

Kaplowitz, M.D., \& Levine, R. (2005). How environmental knowledge measures up at a big ten university. Environmental Education Research, 11(2), 143-160.

Karasar, N. (2014). Bilimsel araştırma yöntemi (26. Baskl). Ankara: Nobel Yayıncılık.

Karataş, A. (2013). Çevre bilincinin geliştirilmesinde çevre eğitiminin rolü ve Niğde Üniversitesi eğitim fakültesi örneği. Yayımlanmamış Doktora Tezi, Ankara Üniversitesi Sosyal Bilimler Enstitüsü, Ankara.

Karpudewan, M. \& İsmail, Z. (2012). Malaysian primary pre-service teachers' understanding and awareness of environmental knowledge. In C. Ghenai (Ed.), sustainable development-education, business and management-architecture and building construction-agriculture and food security, (13-26). Rijeka, Croatia: In Tech.

Köse, S., Gencer Savran, A., Gezer, K., Gezer, G. H. \& Bilen, K. (2011). Investigation of undergraduate students' environmental attitudes. International Electronic Journal of Environmental Education, 1(2), 85-96.

Milfont, T. L., \& Duckitt, J. (2006). Preservation and utilization: understanding the structure of environmental attitudes. Medio Ambiente y Comportamiento Humano, 7, 29-50.

Nargund, G. (2009). Declining birth rate in developed countries: a radical policy re-think is required. Facts Views \& Vision in Obgyn, 1(3), 191-193.

O'Brien, S. R. M. (2007). Indications of environmental literacy: using a new survey instrument to measure awareness, knowledge and attitudes of university-aged students. Unpublished Master Thesis, Iowa State University, Iowa.

Oğuz, D., Çakcı, I., \& Kavas, S. (2011). Yüksek öğretimde öğrencilerin çevre bilinci. Süleyman Demirel Üniversitesi Orman Fakültesi Dergisi, 12, 34-39.

Okşaşoğlu, K. A. (2006). Turizm ve çevre ilişkilerinde bilinç düzeyi: Kundu Antalya bölgesinde bir uygulama çalışması. Yayımlanmamış Yüksek Lisans Tezi, Akdeniz Üniversitesi Sosyal Bilimler Enstitüsü, Antalya.

Oweini, A., \& Houri, A. (2006). Factors affecting environmental knowledge andattitudes among Lebanese college students. Applied Environmental Education and Communication: An International Journal, 5(2), 95-105.

Özer, U. (1993). Yükseköğretimde çevre için eğitim çevre eğitimi. Ankara: Türkiye Çevre Vakfı Yayını.

Özey, R. (2001). Çevre sorunları (2. Baskı). İstanbul: Aktif Yayınevi.

Pandey, V. C. (2006). Environmental F. India: Isha Books.

Pengra, B. (2012). One planet, how many people? A review of earth's carrying capacity (Vol. 20). A discussion, paper for the year of Rio. Erişim tarihi: 11. 07. 2018 https://na.unep.net/geas/archive/pdfs/geas_jun_12_carrying_capacity.pdf

Seçgin, F., Yalvaç, G., \& Çetin, T. (2010). İlköğretim 8. sını öğrencilerinin karikatürler aracılığıyla çevre sorunlarına ilişkin algıları. International Conference on New Trends in Educationand Their Implications, 391-398. 
Straughan, R. D. \& Roberts, J. A. (1999). Environmental segmentation alternatives: a look at green consumer behavior in the new millennium. Journal of Consumer Marketing, 16(6), 558-575.

Şama, E. (2003). Öğretmen adaylarının çevre sorunlarına yönelik tutumları. Gazi Eğitim Fakültesi Dergisi, 23(2), 99-110.

Şimşekli, Y. (2004). Çevre bilincinin geliştirilmesine yönelik çevre eğitimi etkinliklerine ilköğretim okullarının duyarlılığı. Uludă̆ Üniversitesi Eğitim Fakültesi Dergisi, 17(1), 8392.9999999999999999,

Talay, İ., Gündüz, S., Akpınar, N. (2004). On the status of environmental education and awareness of undergraduate students at Ankara University. International Journal of Environment and Pollution, 21(3), 293-308.

Titiz, M. T. (1995). Çevre sorunları mı? Yoksa çevrede kristalleşen sorunlar mı? Yeni Türkiye Dergisi, 12(5), 53-57.

Uzun, N. (2007). Ortaöğretim öğrencilerinin çevreye yönelik bilgi ve tutumlar üzerine bir çalısma. Yayımlanmamış Doktora Tezi, Hacettepe Üniversitesi Eğitim Bilimleri Enstitüsü, Ankara.

Uzun, N., \& Sağlam, N. (2007). Ortaöğretim öğrencilerinin çevreye yönelik bilgi ve tutumlarına "çevre ve insan" dersi ile gönüllü çevre kuruluşlarının etkisi. Hacettepe Üniversitesi Eğitim Fakültesi Dergisi, 33(33).

Ünal, S., \& Dımışlı, E. (1999). UNESCO-UNEP himayesinde çevre eğitiminin gelişimi ve Türkiye'de ortaöğretim çevre eğitimi. Hacettepe Üniversitesi Eğitim Fakültesi Dergisi, 17(17), 142-154.

Varınca, K. B. (2011). Çevre sorunları-nüfus artışı ilişkisinin irdelenmesi, X. Ulusal Ekoloji ve Çevre Kongresi Bildiri Özet Kitabı, 66.

Wenden, A. L. (2004). Integrating education for social and ecological peace-the educational context. A. L. Wenden. (ed.), educating for a culture of social and ecological peace. Albany, USA: State University of New York Press.

Yücel, M., Uslu, C., Altunkasa, F., Güçray, S. S., \& Peker Say, N. (2008). Adana'da halkın çevre duyarlılığının saptanması ve bu duyarlılığı arttırabilecek önlemlerin geliştirilmesi. Adana Kent Sorunları Sempozyumu, TMMOB Yayın, 363- 432.7 